\title{
Bone Marrow Myeloid Stem Cell
}

National Cancer Institute

\section{Source}

National Cancer Institute. Bone Marrow Myeloid Stem Cell. NCI Thesaurus. Code C12552.

A hematopoietic stem cell found in the bone marrow that is committed to form erythrocytes, megakaryocytes, and all leukocytes except lymphocytes. 